\title{
Elemental Status and Lipid Peroxidation in the Blood of Children with Endemic Fluorosis
}

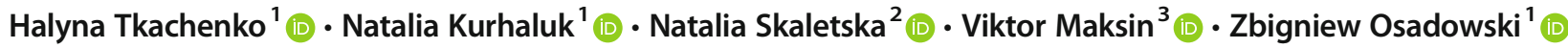

Received: 24 February 2020 / Accepted: 8 June 2020 / Published online: 17 June 2020

(C) The Author(s) 2020

\begin{abstract}
The study aimed to assess the levels of trace elements, minerals, and toxic elements as well as lipid peroxidation biomarkers (lipid acyl hydroperoxides, 2-thiobarbituric acid reactive substances (TBARS)) in the blood of children with chronic fluorosis from endemic fluorosis areas (Sosnivka village, Lviv region, western Ukraine). The results were compared with healthy children from Staryi Sambir (Lviv region, western Ukraine), whose drinking water contained permissible levels $(<1 \mathrm{ppm})$ of fluoride. Thirtyone children from the Sosnivka village in the Lviv region, including 16 females and 15 males aged 7-10 years, with clinically diagnosed fluorosis, were recruited for the study. The children had been exposed to fluoride (>1.5 ppm) through drinking water for more than 5 years. In the blood, eight macro- and microelements (calcium, zinc, potassium, iron, copper, selenium, manganese, chromium), five additional elements (sulfur, bromine, chlorine, nickel, strontium), and four toxic elements (lead, mercury, cadmium, mercury) were assessed with the X-ray fluorescence method. The results of our study demonstrated a 14-fold decrease in the copper level, a 2.5-fold decrease in the calcium and zinc levels, and a 2-fold decrease in the selenium level in the blood of children with chronic fluorosis compared with the healthy children from the non-fluorosis area. In turn, a 1.7- and 1.4-fold increase in the strontium and lead content, respectively, was noted. The sulfur, chlorine, potassium, calcium, copper, zinc, and selenium levels in the blood samples of children with chronic fluorosis were lower than the reference value. The children had higher blood TBARS levels, while the acyl hydroperoxide levels were non-significantly increased in comparison with healthy children living in the non-fluorosis area. Additionally, the bromine level was correlated positively with the selenium level and acyl hydroperoxides. However, more studies are needed to clarify the relationship between blood mineral status, oxidative stress biomarkers, and chronic fluorosis.
\end{abstract}

Keywords Fluorosis $\cdot$ Oxidative stress $\cdot$ Lipid peroxidation $\cdot$ Chemical elements $\cdot$ Blood $\cdot$ Ukraine

\section{Introduction}

Although fluoride is considered an essential trace element, given its role in imparting stability to teeth and bones, chronic exposure to (>1 ppm) fluoride is known to cause toxic effects $[8,33,38,55]$. Long-term exposure to high levels of fluoride is a serious health problem in many parts of the world where

Natalia Kurhaluk

natalia.kurhaluk@apsl.edu.pl; nataliakurhaluk@gmail.com

1 Department of Biology, Institute of Biology and Earth Sciences, Pomeranian University in Stupsk, Arciszewski Str. 22b, 76-200 Słupsk, Poland

2 Danylo Halytskyy Lviv National Medical University, Lviv, Ukraine

3 National University of Life and Environmental Sciences of Ukraine, Kyiv, Ukraine drinking water contains more than $1-1.5 \mathrm{ppm}$ of fluoride [33, $38,48,61]$.

Fluorosis is a well-defined clinical entity characterized by toxic effects of high fluoride intake on teeth, bones, and soft tissues $[9,24,34]$. In addition to its well-known effects on the skeleton and teeth, fluorosis can also adversely affect many tissues and organs, such as the liver and kidneys, with a broad array of symptoms and various pathological changes [27, 41]. Fluoride can cross cell membranes by simple diffusion and enter soft tissues [61]. The liver is one of the target organs attacked by fluoride. Numerous studies have revealed that excessive amounts of fluoride disturb the metabolic processes and detoxication capabilities of the liver [16]. Fluorideinduced necrosis, modifications of membrane lipids, and apoptosis in hepatocytes are associated with oxidative stress [19]. Kidneys play a prominent role in fluoride metabolism, as $50-80 \%$ of fluoride is removed via urinary excretion [23]. There was a close correlation between fluoride intake and 
renal injury. Fluoride-intoxicated rats showed an increased generation of reactive oxygen species (ROS) and lipid peroxidation in the kidneys [22]. In endemic fluorosis areas, drinking water with fluoride levels over $2.0 \mathrm{ppm}$ can cause damage to the liver and kidney functions in children [56].

Recent studies have shown that fluoride exerts different cellular effects in time-, concentration-, and cell typedependent manner on the cell machinery leading to cell death, apoptosis, and/or necrosis both in vivo and in vitro [2]. The main toxic effect of fluoride in cells consists of its interaction with enzymes [1]. Fluoride at micromolar levels is considered an effective anabolic agent promoting cell proliferation, whereas millimolar concentrations inhibit several enzymes, including phosphatases, both in vivo and in vitro $[2,30]$. Fluoride can interact with a wide range of cellular processes such as gene expression, cell cycle, proliferation and migration, respiration, metabolism, ion transport, secretion, endocytosis, apoptosis/necrosis, and oxidative stress, and that these mechanisms are involved in a wide variety of signaling pathways [2].

Oxygen radical generation and lipid peroxidation have even been proposed to be an important mediating factor in the detrimental effects of chronic fluoride toxicity [17, 35]. However, how the whole body effects are produced is still unclear, and efforts to prevent and treat fluorosis by therapeutic measures have had only limited success [17].

Children living in territories with increased fluoride very often exhibit problems with normal physical maturity and bone formation as a result of exposure at the sensitive developmental stages, particularly the pre- and postnatal ontogenesis period, the first year of life, and during puberty period [12, 54]. Clinical symptoms in children include rachitis, osteoporosis, and disorders of the calcium homeostasis balance [12, 49].

In Central Europe, groundwater resources that exceed the upper guideline value of $1.5 \mathrm{ppm}$ are widespread, and dental fluorosis associated with high fluoride concentrations in water has been reported in Ukraine, Moldova, and Hungary [12, 14, $15,36,64]$. The information about the prevalence of fluorosis in Ukraine demonstrates that the relationships between fluorosis and fluoride concentrations in water are not simple [12]. Although it is often the case that waters containing $>1.5 \mathrm{ppm}$ cause disease, the disease also occurs in areas where water fluoride contents are below $1.5 \mathrm{ppm}$ and this may be due to other water chemistry factors, other non-water sources of fluoride, and dietary or physiological factors in the areas concerned [12].

In Ukraine, an assessment of two industrial regions, Chervonohrad in the west and Kharkiv-Dnipro-DonetskZaporizhia in the central-eastern part of Ukraine conducted by Fordyce and Vrana (2001) and Fordyce and co-workers (2007) revealed that sources related to coal mining resulted in enhanced fluoride in the environment of Chervonohrad, but had little impact on water fluoride concentrations in Kharkiv-
Dnipro-Donetsk-Zaporizhia. These findings were incorporated into the national risk assessment for Ukraine $[11,12]$. In the Chervonohrad Mining District (Lviv region, Ukraine), highfluoride waters associated with tectonically active fault zones and mining contamination result in dental fluorosis in the local population (64\% prevalence rate). Alternative lower fluoride waters have been supplied to the public in recent years, but the disease is still endemic in the region. Defluoridation technologies may be helpful in this area. We performed the current study in this endemic fluorosis area in the Lviv region (western part of Ukraine).

Minerals and trace elements are necessary for both physiological and biochemical functions. Many disorders in the organism are related to altered serum mineral and trace element levels. Deficiency of essential trace elements or minerals and excess of potentially harmful trace elements or minerals are both known to have adverse effects in the general population [10]. Therefore, this study aimed to assess the levels of trace elements, minerals, and toxic elements as well as lipid peroxidation biomarkers in the blood of children with chronic fluorosis from endemic fluorosis areas (Sosnivka village, Lviv region, western Ukraine, $50^{\circ} 17^{\prime} 40^{\prime \prime} \mathrm{N} 24^{\circ} 15^{\prime} 00^{\prime \prime} \mathrm{E}$ ). The results were compared with healthy children from the Staryi Sambir (Lviv region, western Ukraine, $49^{\circ} 26^{\prime} 28^{\prime \prime} \mathrm{N} 23^{\circ} 00^{\prime}$ $29^{\prime \prime} \mathrm{E}$ ), whose drinking water contained permissible levels (< $1 \mathrm{ppm})$ of fluoride.

\section{Materials and Methods}

Subjects Thirty-one children from the Sosnivka village (Lviv region), including 16 females (mean height $1.33 \pm 0.02 \mathrm{~m}$ and mean bodyweight $30.3 \pm 1.67 \mathrm{~kg})$ and 15 males $(1.31 \pm$ $0.02 \mathrm{~m}$ and $28.88 \pm 1.75 \mathrm{~kg}$ ) aged $7-10$ years, with clinically defined fluorosis were recruited for the study, with written consent from their parents. These children had been exposed to fluoride (>1.5 ppm) through drinking water for more than 5 years. Physical examination was performed in all children. The children were also examined for having mottled tooth enamel, which is one of the diagnostic criteria of endemic fluorosis (according to Dean's index). Body weight and height were recorded as well. The exclusion criteria of the study were the presence of any known cardiac and lung diseases, the use of cardiac drugs, diabetes mellitus, chronic renal disorders, and hepatic diseases. The participants who had taken any vitamin or mineral supplements for at least 2 weeks before blood samples were also excluded. Informed written consent was obtained from all parents. The study protocol was approved by the Institutional Human Ethical Committee (Danylo Halytskyy Lviv National Medical University, Lviv, Ukraine, No. 5 of May 26, 2014). Fifteen healthy children, i.e., 5 females (mean height $1.40 \pm 0.02 \mathrm{~m}$ and mean bodyweight $33.12 \pm 2.66 \mathrm{~kg})$ and 9 males $(1.38 \pm 0.02 \mathrm{~m}$ and $32.37 \pm$ 
$2.14 \mathrm{~kg})$ in the age range of $7-11$ years $(8.09 \pm 0.33 \mathrm{~m}$ and $7.95 \pm 0.29 \mathrm{~kg}$ ) from the Staryi Sambir city of Lviv region (western Ukraine), whose drinking water contained permissible levels $(<1 \mathrm{ppm})$ of fluoride, served as controls. The clinical history of the children was recorded.

Blood Sample Collection After overnight fasting, blood samples of the subjects were collected by venipuncture into $\mathrm{K}_{3^{-}}$ EDTA and $3.8 \%$ sodium citrate tubes. Plasma and buffy coat were removed by centrifugation at $3000 \mathrm{rpm}$ for $15 \mathrm{~min}$. Erythrocytes were washed 3 times with buffered saline, and the packed cells were then aliquoted for further analysis.

\section{Biochemical Measurements}

Lipid Acyl Hydroperoxide Assay The acyl hydroperoxide level was assessed in the plasma sample with the method proposed by Kamyshnikov (2004). To $0.2 \mathrm{~mL}$ of plasma, $4 \mathrm{~mL}$ of a "heptane-isopropanol" mixture was added and vortexed vigorously. Then, $1 \mathrm{~mL}$ of $\mathrm{HCl}(\mathrm{pH} 2.0)$ and $2 \mathrm{~mL}$ of heptane reagent were added, vortexed, and centrifuged at $3000 \mathrm{rpm}$ for $5 \mathrm{~min}$. The lipid hydroperoxide level was read spectrophotometrically at $233 \mathrm{~nm}$ and expressed as $\mathrm{E}_{233}$ per milliliter. A mixture of distilled water was used in the blank samples [20].

2-Thiobarbituric Acid Reactive Substance Assay The level of lipid peroxidation was determined by quantifying the concentration of 2-thiobarbituric acid reacting substances (TBARS) with the Kamyshnikov (2004) method for determination of the malonic dialdehyde (MDA) concentration. This method is based on the reaction of the degradation of the lipid peroxidation product, MDA, with 2-thiobarbituric acid (TBA) at high temperature and acidity to generate a colored adduct that is measured spectrophotometrically. The $\mu$ mol of MDA per liter was calculated using $1.56 \cdot 10^{5} \mathrm{mM}^{-1} \mathrm{~cm}^{-1}$ as the extinction coefficient [20].

X-ray Fluorescence Analysis of Blood The levels of eight macro- and microelements (calcium, zinc, potassium, iron, copper, selenium, manganese, chromium), five additional elements (sulfur, bromine, chlorine, nickel, strontium), and four toxic elements (lead, mercury, cadmium, mercury) were assessed in the blood of each child with the use of the X-ray fluorescence assay according to X-ray fluorescence analysis (2000) [57]. The total number of analyzed indices was 576. The assessment of the levels of chemical elements in the blood plasma was conducted closely with experts of the Scientific and Technical Center "VIRIA Ltd." (Kyiv, Ukraine). Plasma elemental analyses were conducted using an X-ray fluorescence spectrometer ElvaX (ElvaX, Kyiv, Ukraine). Calibrations were performed before the first use of the spectrometer for sample analysis each day.
Statistical Analysis The results are expressed as mean \pm S.E.M. All variables were tested for normal distribution using the Kolmogorov-Smirnov test $(p>0.05)$. The significance of differences between levels of oxidative stress biomarkers and concentrations of chemical elements (significance level, $p<0.05$ ) was examined using the Kruskal-Wallis test by ranks. Correlations between the parameters at the set significance level were evaluated using Spearman's correlation analysis [60]. All statistical calculations were performed on separate data from each individual with STATISTICA 8.0 software (StatSoft, Krakow, Poland).

\section{Results}

The anthropometric data of the controls and fluorosis-affected children are shown in Table 1. There were no significant differences between the children with fluorosis and the controls in terms of the age, height, body weight, chest circumferences, mid-upper arm muscle circumferences, hip circumferences, and head circumferences.

There was a non-significant $17.5 \%$ increase $(p>0.05)$ in the primary products of lipid peroxidation (acyl hydroperoxides) in the blood of children from the endemic fluorosis areas (Sosnivka village), compared with the values obtained in the blood of the healthy children from the non-fluorosis area (Fig. 1). Moreover, the children with chronic fluorosis had by $25 \%$ higher blood TBARS levels $(p<0.05)$ than the healthy subjects living in the non-fluorosis areas (Staryi Sambir city) (Fig. 1).

In the current study, the levels of eight macro- and microelements (calcium, zinc, potassium, iron, copper, selenium, manganese, chromium), five additional elements (sulfur, bromine, chlorine, nickel, strontium), and four toxic elements (lead, mercury, cadmium, mercury) were assessed and presented in Table 1. The serum S levels $(641.78 \pm 81.62 \mu \mathrm{g} /$

Table 1 Anthropometric data of the controls and fluorosis-affected children $(M \pm m)$

\begin{tabular}{lll}
\hline Anthropometric parameters & $\begin{array}{l}\text { Non-fluorosis } \\
\text { children }\end{array}$ & $\begin{array}{l}\text { Chronic fluorosis } \\
\text { children }\end{array}$ \\
\hline Age (years) & $8.02 \pm 0.31$ & $8.17 \pm 0.34$ \\
Sex (M/F) & $9 / 5$ & $15 / 16$ \\
Height, m & $1.39 \pm 0.03$ & $1.32 \pm 0.02$ \\
Bodyweight, kg & $32.72 \pm 2.39$ & $29.55 \pm 1.72$ \\
Chest circumference, cm & $65.81 \pm 2.24$ & $62.87 \pm 1.60$ \\
$\begin{array}{c}\text { Mid-upper arm muscle } \\
\text { circumference, cm }\end{array}$ & $20.83 \pm 0.89$ & $20.85 \pm 1.14$ \\
$\begin{array}{l}\text { Hip circumference } \\
\text { maximum, cm }\end{array}$ & $37.81 \pm 1.59$ & $37.05 \pm 1.53$ \\
Head circumference, cm & $27.86 \pm 0.97$ & $27.23 \pm 0.99$ \\
\hline
\end{tabular}


Fig. 1 Levels of acyl hydroperoxides and TBARS in the blood of children living in endemic fluorosis areas (Sosnivka village, Sokal district, Lviv region) and healthy children from the non-fluorosis areas (Staryi Sambir city, Staryi Sambir district, Lviv region). The asterisk indicates that changes are statistically significant compared with the group of children from the non-fluorosis areas $(p<0.05)$

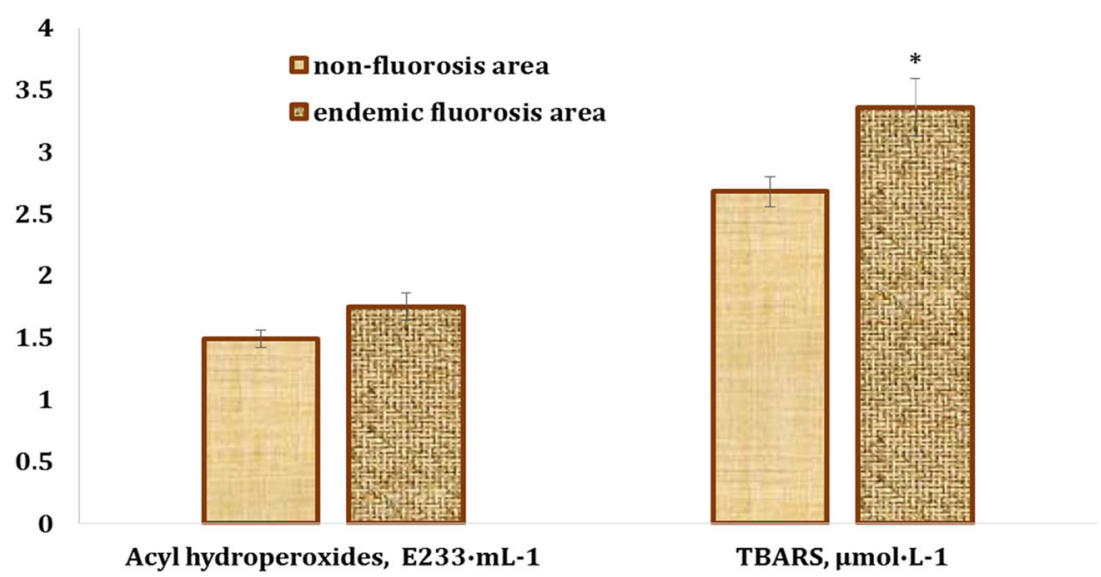

$\mathrm{mL}$ vs. $1035.19 \pm 51.83 \mu \mathrm{g} / \mathrm{mL}$, respectively, decreased by $38 \%, p<0.01)$, Cl levels $(1458.306 \pm 169.466 \mu \mathrm{g} / \mathrm{mL}$ vs. $2561.93 \pm 253.83 \mu \mathrm{g} / \mathrm{mL}$, respectively, decreased by $43 \%$, $p<0.05), \mathrm{K}$ levels $(117.53 \pm 14.58 \mu \mathrm{g} / \mathrm{mL}$ vs. $141.84 \pm$ $8.94 \mu \mathrm{g} / \mathrm{mL}$, respectively, decreased by $17 \%, p<0.05), \mathrm{Ca}$ levels $(36.94 \pm 4.43 \mu \mathrm{g} / \mathrm{mL}$ vs. $91.64 \pm 3.06 \mu \mathrm{g} / \mathrm{mL}$, respectively, decreased by $60 \%, p<0.01), \mathrm{Cu}$ levels $(0.248 \pm$ $0.038 \mu \mathrm{g} / \mathrm{mL}$ vs. $3.488 \pm 0.458 \mu \mathrm{g} / \mathrm{mL}$, respectively, decreased by $93 \%, p<0.01)$, Zn levels $(0.665 \pm 0.072 \mu \mathrm{g} / \mathrm{mL}$ vs. $0.665 \pm 0.072 \mu \mathrm{g} / \mathrm{mL}$, respectively, decreased by $58 \%$, $p<0.01)$, and Se levels $(0.041 \pm 0.005 \mathrm{mg} / \mathrm{mL}$ vs. $0.074 \pm$ $0.006 \mathrm{mg} / \mathrm{mL}$, respectively, decreased by $45 \%, p<0.01)$ were significantly lower in the children with chronic fluorosis than in the controls (Table 2). There were no statistically significant differences in the serum levels of $\mathrm{Fe}, \mathrm{Ni}, \mathrm{Br}, \mathrm{Cr}$, and $\mathrm{Mn}$ between the fluorosis group and the control group. Moreover, the serum Sr level was statistically significantly higher $(0.0781 \pm 0.0168 \mu \mathrm{g} / \mathrm{mL}$ vs. $0.046 \pm 0.0057 \mu \mathrm{g} / \mathrm{mL}$, respectively, decreased by $70 \%, p<0.05)$ in the children with chronic fluorosis than in the controls, whereas the $\mathrm{Hg}, \mathrm{Cd}$, and $\mathrm{Pb}$ levels were statistically non-significant (Table 2).

The serum $\mathrm{S}, \mathrm{Cl}, \mathrm{K}, \mathrm{Ca}, \mathrm{Cu}, \mathrm{Zn}$, and Se levels in the children with chronic fluorosis were lower but the Fe levels were higher than the reference values. In the control group, the $\mathrm{S}$, $\mathrm{Cl}$, and $\mathrm{Zn}$ levels were lower than the reference values (Table 2).

The correlation analysis is presented in Table 3 . In the blood samples of the children from the non-fluorosis areas,
Table 2 Comparison of the serum levels of trace elements, minerals, and toxic heavy metals in non-fluorosis children and chronic fluorosis children, $\mu \mathrm{g} / \mathrm{mL}$ $(M \pm m)$

\begin{tabular}{llll}
\hline Chemical elements & Non-fluorosis children & $\begin{array}{l}\text { Chronic fluorosis } \\
\text { children } \\
M \pm m\end{array}$ & $\begin{array}{l}\text { Reference values } \\
\text { according to } \\
\text { http://www.viria.com.ua) }\end{array}$ \\
\hline Sulfur, $\mathrm{S}$ & $1035.19 \pm 51.83$ & $641.78 \pm 81.62^{* *}$ & $1050-1200$ \\
Chlorine, $\mathrm{Cl}$ & $2561.93 \pm 253.83$ & $1458.306 \pm 169.466^{*}$ & $3400-3800$ \\
Potassium, $\mathrm{K}$ & $141.84 \pm 8.94$ & $117.53 \pm 14.58^{*}$ & $140-207$ \\
Calcium, $\mathrm{Ca}$ & $91.64 \pm 3.06$ & $36.94 \pm 4.43^{* *}$ & $90-110$ \\
Iron, $\mathrm{Fe}$ & $1.479 \pm 0.133$ & $1.96 \pm 0.35$ & $0.6-1.6$ \\
Nickel, $\mathrm{Ni}$ & $0.024 \pm 0.0023$ & $0.0237 \pm 0.0027$ & $0.02-0.03$ \\
Bromine, $\mathrm{Br}$ & $237.22 \pm 53.75$ & $248.068 \pm 64.992$ & $50-1500$ \\
Copper, $\mathrm{Cu}$ & $3.488 \pm 0.458$ & $0.248 \pm 0.038^{* *}$ & $1.3-16$ \\
Zinc, $\mathrm{Zn}$ & $0.665 \pm 0.072$ & $0.277 \pm 0.0756^{* *}$ & $0.7-1.2$ \\
Chrome, $\mathrm{Cr}$ & $0.0653 \pm 0.024$ & $0.0475 \pm 0.0064$ & $0.03-0.12$ \\
Manganese, $\mathrm{Mn}$ & $0.0607 \pm 0.0071$ & $0.053 \pm 0.0066$ & $0.04-0.16$ \\
Selenium, Se & $0.074 \pm 0.006$ & $0.041 \pm 0.005^{* *}$ & $0.07-0.15$ \\
Strontium, Sr & $0.046 \pm 0.0057$ & $0.0781 \pm 0.0168^{*}$ & $0.04-0.13$ \\
Mercury, $\mathrm{Hg}$ & $0.014 \pm 0.0027$ & $0.0119 \pm 0.00187$ & $0.01-0.05$ \\
Cadmium, $\mathrm{Cd}$ & $0.01 \pm 0.0011$ & $0.01 \pm 0.0011$ & $0.01-0.027$ \\
Lead, $\mathrm{Pb}$ & $0.0446 \pm 0.0073$ & $0.064 \pm 0.015$ & $0.05-0.2$ \\
\hline
\end{tabular}

$* p<0.05 ; * *<0.001$ compared with the value of children from the non-fluorosis area 
Table 3 Correlation analysis between the chemical elements and oxidative stress biomarker levels in the blood of chronic fluorosis children and healthy children from the non-fluorosis areas

\begin{tabular}{|c|c|c|c|}
\hline Relations & $\begin{array}{l}\text { Spearman's correlation } \\
\text { coefficients, } r\end{array}$ & $\mathrm{t}(\mathrm{N}-2)$ & $p$ level \\
\hline \multicolumn{4}{|c|}{ Non-fluorosis children } \\
\hline $\mathrm{S}$ vs. $\mathrm{Br}$ & -0.638 & -2.992 & 0.010 \\
\hline S vs. Hg & -0.584 & -2.592 & 0.022 \\
\hline S vs. TBARS & 0.581 & 2.472 & 0.029 \\
\hline K vs. Cr & -0.659 & -3.160 & 0.008 \\
\hline $\mathrm{K}$ vs. $\mathrm{Pb}$ & 0.556 & 2.316 & 0.039 \\
\hline $\mathrm{Ni}$ vs. $\mathrm{Cu}$ & -0.612 & -2.788 & 0.015 \\
\hline Ni vs. Mn & -0.565 & -2.467 & 0.028 \\
\hline Cr vs. Mn & 0.533 & 2.268 & 0.041 \\
\hline Sr vs. Hg & 0.593 & 2.652 & 0.020 \\
\hline \multicolumn{4}{|c|}{ Chronic fluorosis-affected children } \\
\hline $\mathrm{S}$ vs. $\mathrm{Cu}$ & 0.761 & 5.862 & 0.000 \\
\hline $\mathrm{S}$ vs. $\mathrm{Zn}$ & 0.732 & 5.378 & 0.000 \\
\hline $\mathrm{S}$ vs. Se & 0.478 & 2.718 & 0.012 \\
\hline $\mathrm{Cl}$ vs. $\mathrm{K}$ & 0.382 & 2.065 & 0.049 \\
\hline K vs. Zn & -0.564 & -3.413 & 0.002 \\
\hline $\mathrm{Cu}$ vs. $\mathrm{Zn}$ & 0.701 & 4.909 & 0.000 \\
\hline $\mathrm{Zn}$ vs. $\mathrm{Br}$ & 0.459 & 2.586 & 0.016 \\
\hline Zn vs. Se & 0.626 & 4.015 & 0.000 \\
\hline Br vs. Se & 0.394 & 2.144 & 0.042 \\
\hline Br vs. AHP & 0.415 & 2.279 & 0.031 \\
\hline
\end{tabular}

the sulfur level was correlated positively with the TBARS level $(r=0.581, p=0.029)$ and inversely with both $\mathrm{Br}(r=$ $-0.638, p=0.010)$ and $\mathrm{Hg}(r=-0.584, p=0.022)$. The potassium level was correlated positively with the lead level $(r=$ $0.556, p=0.039)$ and inversely with the chromium level $(r=$ $-0.659, p=0.039)$. The nickel level was correlated inversely with copper $(r=-0.612, p=0.015)$ and manganese $(r=-$ $0.565, p=0.028)$, while the manganese level correlated positively with the chromium level $(r=0.593, p=0.020)$ (Table 3).

In the blood samples of the children with chronic fluorosis, the sulfur level was correlated positively with copper $(r=$ $0.761, p=0.000)$, zinc $(r=0.7321, p=0.000)$, and selenium $(r=0.478, p=0.012)$. The potassium level was correlated positively with chlorine $(r=0.382, p=0.049)$ and inversely with the zinc level $(r=-0.564, p=0.002)$. The zinc level was correlated positively with copper $(r=0.701, p=0.000)$, bromine $(r=0.459, p=0.016)$, and selenium levels $(r=0.626$, $p=0.000$ ), while the bromine level correlated positively with the content of selenium $(r=0.394, p=0.042)$ and acyl hydroperoxides $(r=0.415, p=0.031)$ (Table 3). Additionally, the height of the children was correlated positively with calcium $(r=0.200, p=0.021)$, zinc $(r=0.253, p=0.004)$, and strontium levels $(r=0.223, p=0.011)$, whereas their age was correlated positively with the content of zinc $(r=0.253, \mathrm{p}=$ $0.004)$ and selenium $(r=0.173, p=0.048)$.

\section{Discussion}

The current study has focused on lipid peroxidation biomarkers in the blood of children with chronic fluorosis living in endemic fluorosis areas. The results of the present study showed that children with chronic fluorosis had higher blood TBARS levels, while the acyl hydroperoxide levels were nonsignificantly increased, in comparison with the healthy children living in the non-fluorosis areas (Fig. 1). Moreover, the results also demonstrated a 14-fold decrease in the copper level, a 2.5 -fold decrease in the calcium and zinc levels, and a 2-fold decrease in the selenium level in the blood of children with chronic fluorosis, compared with the healthy children from the non-fluorosis areas. In turn, there was a 1.7- and 1.4-fold increase in the strontium and lead content, respectively. The sulfur, chlorine, potassium, calcium, copper, zinc, and selenium levels in the blood samples of children with chronic fluorosis were lower than the reference value (Table 2). Only two correlative relationships were observed between element levels and lipid peroxidation biomarkers. In the blood samples of the children with chronic fluorosis, the blood acyl hydroperoxide levels were correlated with the bromine levels $(r=$ $0.415, p=0.031$ ) (Table 3 ). TBARS level was positively correlated with sulfur level $(r=0.581, p=0.029)$ in the blood of healthy children from the non-fluorosis areas. Moreover, there were no significant differences in the anthropometric data between the fluorosis-affected children and the controls (Table 1).

It is known that fluoride is an inducer of oxidative stress and modulates intracellular redox homeostasis, lipid peroxidation, and protein oxidation. It also alters gene expression and causes apoptosis [2]. The association between fluoride toxicity and elevated oxidative stress has been widely reported in humans and experimental animals $[2,43,44,51,53,58,59$, 63]. Fluoride exposure increases the generation of anion superoxide $\left(\mathrm{O}_{2}^{--}\right)$[13]. An increased $\mathrm{O}_{2}^{-\cdot}$ concentration and its downstream consequences such as hydrogen peroxide, peroxynitrite, and hydroxyl radicals seem particularly important in mediating the effects of fluoride. Moreover, fluoride increases NO generation and can react with superoxide to form peroxynitrite and with thiols and metal centers in proteins to form nitrosyl adducts [26]. It has also been shown to interfere with the disulfide-bond formation and result in the accumulation of misfolded proteins in the endoplasmic reticulum, causing stress and ROS production [2]. It is known that excessive ROS production leads to macromolecule oxidation, resulting in a free radical attack on membrane phospholipids with resulting membrane damage via induction of lipid peroxidation, mitochondrial membrane depolarization, and 
apoptosis [2]. The results of our study revealed an increase in the TBARS level, i.e., a biomarker of lipid peroxidation, in the blood of the children with chronic fluorosis (Fig. 1).

In our study, decreased serum levels of $\mathrm{Cu}$ and $\mathrm{Zn}$ in children with chronic fluorosis were observed (Table 2). In our opinion, the low $\mathrm{Cu}$ and $\mathrm{Zn}$ levels in the fluorosis-affected children may be associated with fluoride-induced oxidative stress. Ersoy and co-workers (2011) also showed decreased serum levels of $\mathrm{Zn}$ in patients with chronic fluorosis. Increased utilization of $\mathrm{Cu}$ and $\mathrm{Zn}$ for counteracting fluoride-induced oxidative stress may also be, at least partially, responsible for the decrease in the blood level of these elements [10]. Singh (1984) also showed significantly reduced liver and kidney levels of $\mathrm{Zn}, \mathrm{Cu}$, and $\mathrm{Mn}$ in fluoridetreated mice. $\mathrm{Zn}$ is transported in an albumin-bound form [45]. Bennis and co-workers (1993) showed that plasma proteins decreased in chronic fluoride poisoning [4]. Therefore, decreased plasma proteins might be a factor for the decreased serum $\mathrm{Zn}$ concentration in fluorosis patients. Additionally, reduced gastrointestinal absorption and tissue-specific absorption of $\mathrm{Zn}$ may also have contributory effects [10].

Oxidative stress is a recognized mode of action of fluoride exposure that has been observed in vitro in several types of cells and in vivo in soft tissues such as the liver, kidney, brain, lungs, and testes in animals and people living in areas of endemic fluorosis [2]. Fluoride is thought to inhibit the activity of antioxidant enzymes such as superoxide dismutase (SOD), glutathione peroxidase, and catalase [13]. Moreover, fluoride can alter glutathione levels, often resulting in excessive production of ROS at the mitochondrial level, leading to damage to cellular components [2, 32, 37].

Antioxidant treatment consistently protects cells from lipid peroxidation caused by fluoride exposure, suggesting that oxidative/nitrosative damage is the major mode of action of fluoride $[18,32]$. In our previous study [47, 50], we revealed that the oxidative stress in the blood of fluorosis-affected children caused impairments in the antioxidant defenses. Specifically, superoxide dismutase, catalase, glutathione reductase, and glutathione peroxidase activity were decreased. Decreased blood $\mathrm{Cu}$ and $\mathrm{Zn}$ levels may play the main role in the decrease in SOD activity. Uauy and co-workers (1985) demonstrated decreased $\mathrm{Cu} / \mathrm{Zn}$-SOD activity in 17 infants during $\mathrm{Cu}$ deprivation, which may be improved when $\mathrm{Cu}$ is added to the diet. SOD was correlated with plasma $\mathrm{Cu}$; thus, the erythrocyte SOD activity is a good marker of $\mathrm{Cu}$ nutrition in humans [52].

We also found reduced serum selenium levels in children with fluorosis (Table 2). Selenium is a cofactor required for the activity of several seleno-enzymes involved in stressinduced responses and maintenance of high tissue antioxidant levels [3]. Selenium in a certain concentration range was involved in excretion of high fluoride, regulation of free radicals and lipid metabolism disorder, and promotion of recovery in rats with fluorosis. Moreover, Se was able to antagonize high fluoride levels as well as delay and reduce the occurrence of skeletal fluorosis in rats [62]. The antioxidative nature of selenium coupled with its reversal effect on metabolic enzymes in the brain of mice treated with fluoride suggests its use as an antidote agent against fluorosis [39]. The ameliorative effect of selenium is related to its role in various physiological functions, including its role as a biologically active antioxidant. Selenium is an essential component of antioxidant enzyme glutathione peroxidase (GSH-Px). In a certain concentration range, it was involved in excreting high fluorine levels, adjusting free radicals and lipid metabolism disorders, and elevating the antioxidant capacity of fluorosis. Results reported by Reddy and co-workers (2009) indicated that selenium could antagonize long-term fluoride exposure. The optimum level of selenium for the antagonistic effect is $1.5 \mathrm{mg} / \mathrm{L}$. Thus, selenium plays a critical role in the maintenance of the proper blood antioxidant capacity [39]. In our previous study, low selenium levels induced a decrease in blood GSH-Px activity in the serum of children with chronic fluorosis [47, 50].

Although there are many studies on the effect of fluoride on trace elements in experimental animals, few studies on serum trace element levels have been carried out in patients with endemic fluorosis [10]. In humans, there are some investigations of the effects of chronic fluorosis on micronutrient mineral levels. Meral and co-workers (2004) found a significant decrease in the serum levels of $\mathrm{Cu}, \mathrm{Zn}, \mathrm{Mn}$, and $\mathrm{Mg}$ in 15 fluorosis patients [31]. Similarly, Chen and co-workers (2002) found a significant decrease in the serum concentrations of $\mathrm{Ca}$, $\mathrm{Mg}$, and $\mathrm{Cu}$, and an increase in serum $\mathrm{Fe}$ in skeletal fluorosis patients [5]. Ersoy and co-workers (2011) determined the serum levels of trace elements, including serum $\mathrm{Cu}$ and $\mathrm{Zn}$ as well as serum levels of minerals such as $\mathrm{Ca}, \mathrm{P}, \mathrm{Mg}, \mathrm{Na}$, and $\mathrm{K}$ in patients with endemic fluorosis. The study group consisted of 30 patients with endemic fluorosis. Thirty age-, gender-, and body mass index-matched healthy volunteers constituted the control group. The serum $\mathrm{Cu}, \mathrm{Zn}$, and $\mathrm{Mg}$ levels were significantly lower in chronic fluorosis patients than in the controls. There were no statistically significant differences in the serum levels of $\mathrm{Na}, \mathrm{K}, \mathrm{Ca}$, and $\mathrm{P}$ between the fluorosis patients and the control group [10]. Ersoy and co-workers (2011) found that chronic fluorosis was associated with reduced serum levels of $\mathrm{Cu}, \mathrm{Zn}$, and $\mathrm{Mg}$. Singh and Kanwar (1981) investigated changes in $\mathrm{Cu}$ and $\mathrm{Fe}$ in certain tissues in experimental fluorosis. These researchers reported reduced concentrations of $\mathrm{Cu}$ in the liver, kidney, and bone of fluoride-intoxicated mice along with increased $\mathrm{Fe}$ in these organs [46]. Some research conducted in numerous animal models and humans has shown that $\mathrm{Cu}$ deficiency can cause an increase in the plasma cholesterol concentration [7, 21].

Increased serum levels of strontium and lead in children with chronic fluorosis were observed (Table 2). The lead and strontium levels in the drinking water in Sosnivka village 
were in the range of $0.001-0.023 \mathrm{mg} / \mathrm{L}$ and $0.011-2.08 \mathrm{mg} / \mathrm{L}$, respectively. According to state sanitary norms and rules (Ukrainian state standards 2.2.4-171-10) "Hygienic requirements for drinking water intended for human consumption", the maximum allowable concentration (MAC) of lead and strontium in drinking water is less than 0.01 and $7 \mathrm{mg} / \mathrm{L}$, respectively. In our study, the lead levels in the drinking water in Sosnivka village were 2.3-fold higher than the state standards. A possible relationship between high fluoride levels in water and elevated blood lead and strontium concentrations in the children with fluorosis was suggested. Ecological associations have been reported between the use of silicofluoride compounds (sodium silicofluoride and hydrofluosilicic acid) and $\mathrm{NaF}$ as water fluoridation methods and elevated blood lead concentrations in children [29]. Similar results were observed in children who live in old houses supplied by fluoridated water [28]. It is, therefore, possible that the increased water lead levels observed when fluoride concentrations are between 1 and $2 \mathrm{mg} / \mathrm{L}$ could be severely aggravated in places with high fluoride concentrations in the drinking water [2]. However, a recent study found that fluoride increased blood lead concentrations and lead levels in calcified tissues of animals exposed to low levels of lead, suggesting biological interactions as a possible cause of the epidemiological relationship between high $\mathrm{Pb}$ levels and the fluoridation of drinking water [40]. Sr is considered to accumulate in bone and teeth because it has similar properties to the congener $\mathrm{Ca}$. $\mathrm{Sr}$ is easily incorporated into apatite, and $\mathrm{Sr}^{2+}$ occupies the $\mathrm{Ca}^{2+}$ position in hydroxyapatite, $\mathrm{Ca}_{10}\left(\mathrm{PO}_{4}\right)_{6}(\mathrm{OH})_{2}[25,42]$. $\mathrm{Sr}$ has been essential for laboratory animals but not for humans. However, when incorporated into the bone, it behaves like an essential element, as it acts in the same way as Ca. Regarding the association between $\mathrm{Sr}$ and caries, the $\mathrm{Sr}$ level in enamel increased as the $\mathrm{Sr}$ concentration in drinking water increased, and the prevalence of caries reflected in decayed, missing, and filled surfaces was inversely related to the Sr levels in drinking water and enamel $[6,42]$.

\section{Conclusions}

In conclusion, the results of our study demonstrated a 14-fold decrease in the copper level, a 2.5-fold decrease in the calcium and zinc levels, and a 2-fold decrease of the selenium level in the blood of children with chronic fluorosis, compared with the healthy children from the non-fluorosis areas. In turn, a 1.7- and 1.4-fold increase in the strontium and lead content, respectively, was noted. The sulfur, chlorine, potassium, calcium, copper, zinc, and selenium levels in the blood samples of children with chronic fluorosis were lower than the reference value. The children with chronic fluorosis had higher blood TBARS levels, while the acyl hydroperoxide levels were non-significantly increased, in comparison with the values in the healthy children living in the non-fluorosis areas. Additionally, the bromine level was correlated positively with the selenium level and acyl hydroperoxides. However, further studies are needed to clarify the relationship between blood mineral status, oxidative stress biomarkers, and chronic fluorosis.

\section{Compliance with Ethical Standards}

Conflict of Interest The authors declare that they have no conflict of interest.

Open Access This article is licensed under a Creative Commons Attribution 4.0 International License, which permits use, sharing, adaptation, distribution and reproduction in any medium or format, as long as you give appropriate credit to the original author(s) and the source, provide a link to the Creative Commons licence, and indicate if changes were made. The images or other third party material in this article are included in the article's Creative Commons licence, unless indicated otherwise in a credit line to the material. If material is not included in the article's Creative Commons licence and your intended use is not permitted by statutory regulation or exceeds the permitted use, you will need to obtain permission directly from the copyright holder. To view a copy of this licence, visit http://creativecommons.org/licenses/by/4.0/.

\section{References}

1. Adamek E, Pawłowska-Góral K, Bober K (2005) In vitro and in vivo effects of fluoride ions on enzyme activity. Ann Acad Med Stetin 51(2):69-85

2. Barbier O, Arreola-Mendoza L, Del Razo LM (2010) Molecular mechanisms of fluoride toxicity. Chem Biol Interact 188(2):319 333. https://doi.org/10.1016/j.cbi.2010.07.011

3. Beck MA, Handy J, Levander OA (2004) Host nutritional status: the neglected virulence factor. Trends Microbiol 12(9):417-423. https://doi.org/10.1016/j.tim.2004.07.007

4. Bennis A, Kessabi M, Hamliri A, de La Farge F, Braun JP (1993) Plasma biochemistry of adult goats with chronic fluoride poisoning in Morocco. Fluoride 26:241-246

5. Chen PZ, Yun ZJ, Li T, Gao HX, Hao JT, Qin YP (2002) Relations between endemic fluorosis and chemical elements in environment. Chin J Public Health 18(4):433-434

6. Curzon ME (1985) The relation between caries prevalence and strontium concentrations in drinking water, plaque, and surface enamel. J Dent Res 64(12):1386-1388. https://doi.org/10.1177/ 00220345850640121201

7. Czerny B, Put A, Mysliwiec Z, Juzyszyn Z (2000) The influence of quercetin on some parameters of lipid metabolism in rats chronically exposed to ammonium fluoride. Fluoride 33:27-32

8. Das AA (1996) Fluorosis. In: Bamji MS, Rao NP, Reddy V (eds) Text book of human nutrition. Oxford \& IBH Publishing, New Delhi, pp 424-440

9. DenBesten P, Li W (2011) Chronic fluoride toxicity: dental fluorosis. Monogr Oral Sci 22:81-96. https://doi.org/10.1159/000327028

10. Ersoy IH, Koroglu BK, Varol S, Ersoy S, Varol E, Aylak F, Tamer MN (2011) Serum copper, zinc, and magnesium levels in patients with chronic fluorosis. Biol Trace Elem Res 143(2):619-624. https://doi.org/10.1007/s12011-010-8892-x

11. Fordyce FM, Vrana K (2001) Development of a fluoride risk assessment GIS for Central Europe. Final Report: Water Quality 
Improvements through Fluoride Reduction in Groundwater of Central Europe. Inco-Copernicus 15-CT98-0139

12. Fordyce FM, Vrana K, Zhovinsky E, Povoroznuk V, Toth G, Hope BC, Iljinsky U, Baker J (2007) A health risk assessment for fluoride in Central Europe. Environ Geochem Health 29(2):83-102. https:// doi.org/10.1007/s10653-006-9076-7

13. García-Montalvo EA, Reyes-Pérez H, Del Razo LM (2009) Fluoride exposure impairs glucose tolerance via decreased insulin expression and oxidative stress. Toxicology 263(2-3):75-83. https://doi.org/10.1016/j.tox.2009.06.008

14. Gnatyuk P (1988) Fluorosis and caries of temporal teeth. Stomatology 67(5):67-68

15. Grigoryeva L., Golovko N., Nikolishiyn A., Pavlyenko L. 1993. Fluoride influence on prevalence and intensity of stomatological disease in adolescents of Poltava Oblast. In Conference proceedings - fluoride problems of ecology, biology, medicine, and hygiene. Poltava, pp. 25-26

16. Grucka-Mamczar E, Birkner E, Zalejska-Fiolka J, Machoy Z, Kasperczyk S, Błaszczyk I (2007) Influence of extended exposure to sodium fluoride and caffeine on the activity of carbohydrate metabolism enzymes in rat blood serum and liver. Fluoride 40: 62-66

17. Hassan HA, Abdel-Aziz AF (2010) Evaluation of free radicalscavenging and anti-oxidant properties of black berry against fluoride toxicity in rats. Food Chem Toxicol 48(8-9):1999-2004. https://doi.org/10.1016/j.fct.2010.05.018

18. Hassan HA, Yousef MI (2009) Mitigating effects of antioxidant properties of black berry juice on sodium fluoride induced hepatotoxicity and oxidative stress in rats. Food Chem Toxicol 47(9): 2332-2337. https://doi.org/10.1016/j.fct.2009.06.023

19. He LF, Chen JG (2006) DNA damage, apoptosis and cell cycle changes induced by fluoride in rat oral mucosal cells and hepatocytes. World J Gastroenterol 12(7):1144-1148. https://doi.org/10. 3748/wjg.v12.i7.1144

20. Kamyshnikov VS (2004) A reference book on the clinic and biochemical researches and laboratory diagnostics. MEDpress-inform, Moscow

21. Klevay LM (1987) Dietary copper: a powerful determinant of cholesterolemia. Med Hypotheses 24(2):111-119. https://doi.org/ 10.1016/0306-9877(87)90093-4

22. Kobayashi CA, Leite AL, Silva TL, Santos LD, Nogueira FC, Oliveira RC, Palma MS, Domont GB, Buzalaf MA (2009) Proteomic analysis of kidney in rats chronically exposed to fluoride. Chem Biol Interact 180(2):305-311. https://doi.org/10.1016/j. cbi.2009.03.009

23. Kono K, Yoshida Y, Yamagata H, Watanabe M, Shibuya Y, Doi K (1987) Urinary fluoride monitoring of industrial hydrofluoric acid exposure. Environ Res 42(2):415-420. https://doi.org/10.1016/ s0013-9351(87)80208-6

24. Krishnamachari K (1996) Trace elements in human nutrition and health. WHO, Geneva, pp 187-194

25. LeGeros RZ (1991) Calcium phosphate in oral biology and medicine. Karger, Basel, pp 82-107

26. Liu G, Chai C, Cui L (2003) Fluoride causing abnormally elevated serum nitric oxide levels in chicks. Environ Toxicol Pharmacol 13(3):199-204. https://doi.org/10.1016/S1382-6689(03)00002-4

27. Lu J, Chen H, Xu Q, Zheng J, Liu H, Li J, Chen K (2010) Comparative proteomics of kidney samples from puffer fish Takifugu rubripes exposed to excessive fluoride: an insight into molecular response to fluorosis. Toxicol Mech Methods 20(6): 345-354. https://doi.org/10.3109/15376516.2010.490967

28. Macek MD, Matte TD, Sinks T, Malvitz DM (2006) Blood lead concentrations in children and method of water fluoridation in the United States, 1988-1994. Environ Health Perspect 114(1):130 134. https://doi.org/10.1289/ehp.8319
29. Masters RD, Coplan MJ, Hone BT, Dykes JE (2000) Association of silicofluoride treated water with elevated blood lead. Neurotoxicology 21(6):1091-1100

30. Mendoza-Schulz A, Solano-Agama C, Arreola-Mendoza L, ReyesMárquez B, Barbier O, Del Razo LM, Mendoza-Garrido ME (2009) The effects of fluoride on cell migration, cell proliferation, and cell metabolism in $\mathrm{GH} 4 \mathrm{Cl}$ pituitary tumour cells. Toxicol Lett 190(2):179-186. https://doi.org/10.1016/j.toxlet.2009.07.014

31. Meral I, Demir H, Gunduz H, Mert N, Dogan I (2004) Serum copper, zinc, manganese, and magnesium status of subjects with chronic fluorosis. Fluoride 37(2):102-106

32. Mittal M, Flora SJ (2006) Effects of individual and combined exposure to sodium arsenite and sodium fluoride on tissue oxidative stress, arsenic and fluoride levels in male mice. Chem Biol Interact 162(2):128-139. https://doi.org/10.1016/j.cbi.2006.05.018

33. Moimaz SA, Saliba O, Marques LB, Garbin CA, Saliba NA (2015) Dental fluorosis and its influence on children's life. Braz Oral Res 29:S1806-83242015000100214. https://doi.org/10.1590/18073107BOR-2015.vol29.0014

34. Monsour PA, Kruger BJ (1985) Effect of fluoride on soft tissues in vertebrates (a review). Fluoride 18:53-61

35. Narayanaswamy M, Piler MB (2010) Effect of maternal exposure of fluoride on biometals and oxidative stress parameters in developing CNS of rat. Biol Trace Elem Res 133(1):71-82. https://doi. org/10.1007/s12011-009-8413-y

36. Povoroznuk V, Zhovinsky E, Barhanel I, Voloh O (2001) Impact of increased fluoride concentrations in the water on bone tissue functional state and teeth. Ukrainian Medicine Almanac, Kiev

37. Rao SM, Sherlin HJ, Anuja N, Pratibha R, Priya P, Chandrasekar T (2011) Morphometry of buccal mucosal cells in fluorosis-a new paradigm. Hum Exp Toxicol 30(11):1761-1768. https://doi.org/ $10.1177 / 0960327111400109$

38. Reddy GB, Khandare AL, Reddy PY, Rao GS, Balakrishna N, Srivalli I (2003) Antioxidant defense system and lipid peroxidation in patients with skeletal fluorosis and in fluoride-intoxicated rabbits. Toxicol Sci 72(2):363-368. https://doi.org/10.1093/toxsci/kfg030

39. Reddy KP, Sailaja G, Krishnaiah C (2009) Protective effects of selenium on fluoride induced alterations in certain enzymes in brain of mice. J Environ Biol 30(5 Suppl):859-864

40. Sawan RM, Leite GA, Saraiva MC, Barbosa F Jr, Tanus-Santos JE, Gerlach RF (2010) Fluoride increases lead concentrations in whole blood and in calcified tissues from lead-exposed rats. Toxicology 271(1-2):21-26. https://doi.org/10.1016/j.tox.2010.02.002

41. Shashi A, Bhardwaj M (2011) Study on blood biochemical diagnostic indices for hepatic function biomarkers in endemic skeletal fluorosis. Biol Trace Elem Res 143(2):803-814. https://doi.org/10. 1007/s12011-010-8944-2

42. Shigemi T, Tanaka T, Hayashida Y, Maki K (2008) Study of salivary strontium and silver concentrations in primary school children related to dental caries. Biol Trace Elem Res 123(1-3):80-90. https://doi.org/10.1007/s12011-007-8085-4

43. Shivarajashankara YM, Shivashankara AR, Bhat PG, Rao SH (2001a) Effect of fluoride intoxication on lipid peroxidation and antioxidant systems in rats. Fluoride 34:108-113

44. Shivarajashankara YM, Shivashankara AR, Rao SH, Bhat PG (2001b) Oxidative stress in children with endemic skeletal fluorosis. Fluoride 34:103-107

45. Singh M (1984) Biochemical and cytochemical alterations in liver and kidney following experimental fluorosis. Fluoride 17:81-93

46. Singh M, Kanwar KC (1981) Copper and iron in tissue following experimental fluorosis. Fluoride 14:107-112

47. Skaletska NM, Tkachenko HM (2010) Functional characteristics of blood in children living in an ecologically disadvantaged region. Scientific Herald of the O.O. Bogomolets National Medical University 27:178-179. [In Ukrainian, Abstract in English] 
48. Susheela AK (1999) Fluorosis management programme in India. Curr Sci 77:250-1256

49. Teotia M, Teotia SP, Singh KP (1998) Endemic chronic fluoride toxicity and dietary calcium deficiency interaction syndromes of metabolic bone disease and deformities in India: year 2000. Indian J Pediatr 65(3):371-381. https://doi.org/10.1007/ bf02761130

50. Tkachenko HM, Skaletska NM (2009) The state of the prooxidant and antioxidant system in the blood of children living in an environmentally disadvantaged region. Environment \& Health 50(3): 23-26 [In Ukrainian, Abstract in English]

51. Umarani V, Muvvala S, Ramesh A, Lakshmi BV, Sravanthi N (2015) Rutin potentially attenuates fluoride-induced oxidative stress-mediated cardiotoxicity, blood toxicity and dyslipidemia in rats. Toxicol Mech Methods 25(2):143-149. https://doi.org/10. 3109/15376516.2014.1003359

52. Uauy R, Castillo-Duran C, Fisberg M, Fernandez N, Valenzuela A (1985) Red cell superoxide dismutase activity as an index of human copper nutrition. J Nutr 115(12):1650-1655. https://doi.org/10. $1093 / \mathrm{jn} / 115.12 .1650$

53. Varol E, Icli A, Aksoy F, Bas HA, Sutcu R, Ersoy IH, Varol S, Ozaydin M (2013) Evaluation of total oxidative status and total antioxidant capacity in patients with endemic fluorosis. Toxicol Ind Health 29(2):175-180. https://doi.org/10.1177/ 0748233711428641

54. Vyeltishchyev Y (1995) Ecopathology in childhood. Pediatrics 4: 26-33

55. Whitford GM (1996) The metabolism and toxicity of fluoride. Monogr Oral Sci 16 Rev 2:1-153

56. Xiong X, Liu J, He W, Xia T, He P, Chen X, Yang K, Wang A (2007) Dose-effect relationship between drinking water fluoride levels and damage to liver and kidney functions in children. Environ Res 103(1):112-116. https://doi.org/10.1016/j.envres. 2006.05.008
57. X-ray fluorescence analysis: preparation of liquid samples: Preprint. Eds K.N. Belikov, A.B. Blank, L.P. Eksperiandova [et al.] / Nat. Acad. Sci. of Ukraine. Institute for single crystals; ISC-2000-1. - Kharkov: 2000. - 14 p

58. Yamaguti PM, Simões A, Ganzerla E, Souza DN, Nogueira FN, Nicolau J (2013) Effects of single exposure of sodium fluoride on lipid peroxidation and antioxidant enzymes in salivary glands of rats. Oxidative Med Cell Longev 2013:674593-674597. https:// doi.org/10.1155/2013/674593

59. Yang Y, Huang H, Ba Y, Cheng XM, Cui LX (2015) Effect of oxidative stress on fluoride-induced apoptosis in primary cultured Sertoli cells of rats. Int J Environ Health Res 25(1):1-9. https://doi. org/10.1080/09603123.2014.883595

60. Zar JH (1999) Biostatistical analysis, 4th edn. Prentice Hall Inc., New Jersey

61. Zhang Z, Zhou B, Wang H, Wang F, Song Y, Liu S, Xi S (2014) Maize purple plant pigment protects against fluoride-induced oxidative damage of liver and kidney in rats. Int $J$ Environ Res Public Health 11(1):1020-1033. https://doi.org/10.3390/ijerph110101020

62. Zhang ZG (2008) The study on brain impairment from exposure to fluoride and the intervention of selenium. Adv Psychol Sci 16:475-479

63. Zhou BH, Zhao J, Liu J, Zhang JL, Li J, Wang HW (2015) Fluoride-induced oxidative stress is involved in the morphological damage and dysfunction of liver in female mice. Chemosphere 139: 504-511. https://doi.org/10.1016/j.chemosphere.2015.08.030

64. Zhovinsky E, Povoroznuk V (1998) Fluorine in water of Lvov region and relation with bone diseases. Carpathian-Balkan Geological Association. XVI Congress. Austria: University of Vienna, p. 652

Publisher's Note Springer Nature remains neutral with regard to jurisdictional claims in published maps and institutional affiliations. 